BYLAE: KOFRS, MAART 1961.

\title{
TAAL AS BEHEERSINGSMIDDEL
}

(Rede in verkorte vorm uitgespreek op 17 Februarie 1961 by die aanvaarding van die Professoraat in Afrikaans-Nederlands aan die Potchefstroomse Universiteit vir Christelik Hoër Onderwys).

Ilooggeagte Here Lede van die Raad,

Ilooggeleerde Rektor van die P.U. vir C.H.O.,

Hoogeerwaarde Rektor van die Teologiese Skool,

Geagte Kollegas Professore en Lektore,

Geagte Dames en Here Studente,

Dames en Here,

Ek stel my ten doel om in hierdie rede die heel besondere funksie van taal te behandel dat dit 'n middel is waarmee die mens uitvoering gee aan die skeppingseën ') en die algemene kultuuropdrag ${ }^{2}$ ) wat deur God in die paradys aan hom gegee is, middel dan waarmee die mens die skepping beheers. Hiermee word nie gesê dat taal die enigste beheersingsmiddel is nie en ook nie dat dit die enigste funksie van taal is nie. Ek wil egter ook glad nie voorgee dat ek hiermee die hoogste en laaste woord oor die onderwerp gaan sê nie; nie eens dat ek hierin al die aspekte van hierdie ontsaglike onderwerp gaan aanraak nie. Ek stel my alleen voor om 'n paar gesigspunte nader te belig, om sodoende ook enkele riglyne te probeer aanwys vir die beoefening van die taalwetenskap „In u lig".

Daarmee wil ek ook nie te kenne gee dat ek die eerste is wat hierdie pad oopkap, of dat ek 'n tot dusver onopgemerkte deur oopstoot nie. Vir die siening en formulering van die beskouinge wat hier gestel word, is ek volle erkenning en erkentlikheid verskuldig aan my voorganger en tans nog kollega, prof. F. J. I.abuschagne, wat in woord en geskrif die eintlike pionierswerk gedoen het. Hy het van wat hier gestel word oor taal as beheersingsmiddel, veel meer as net "'n vreemde en ver vermoede" gehad; hy het net nie - sover my kennis strek die lyne van sy funksionele taalbeskouing, wat sonder afwyking of kronkeling op hicrdic eindpunt gerig is, sover deurgetrek nie.

Ook aan baie ander voorgangers op die pad van die taalwetenskap is ek erkenning verskuldig; en al moet baie van wat hulle gesê het, van die hand gewys word, was alles nuttig: geen pad in die wetenskap word verniet of tevergeefs geloop nie, al het dit dikwels die waarde vir ander reisigers dat dit 'n doodloop. straat aunwys.

1. Gen. 1 : 28b: .... onderwerp (die aarde) en heers oor die visse van die see en die voëls van die hemel en oor al die diere van die veld".

2. Gen. $2: 15 b: \ldots$ hom in die tuin van Eden gestel om dit te bewerk en te bewark". 
In nederigheid moet ook leely word dat ons wat die wetenskap onder die prisma van die Woord van God stel, nie daarmee te kenne gee dat ons die enigste kennis in pag het en groter en wyser wetenskaplikes is as die wat dit nie doen nie. Inteendeel, dit stem ons eerder tot die ootmoedige helydenis dat ons ook maar "dleur 'n spieël in 'n raaisel kyk" (1 Kor. 13 : 12), ook maar "'n klein leeginsel van die gehoorsaamheid het" (Heid. Kateg., antw. 114).

En wat is wetenskapsheoefening per slot van sake anders as gehoorsaamheid? Dit is gehoorsaamheid aan die opdrag van Cod in sy skeppingseën en kultuurgehod: brheersing van die skepping. En agter hierdie onderwerping en beheersing is in die reël die taal die middel, behalwe dikwels waar die beheersing tegniek of meganiese daad geword het ${ }^{3}$ ) - 'n handeling soos die wat D. J. Opperman in „Ballade van die grysland" só teken:

En haar hande, soos oor 'n klavier,

gryp en vou en gryp en vou

stukke sjokola in blinkpapier -

waar die rede gestol en die denke leeg geword het in bloot masjinale daad. Maar selfs om hiertoe te kom, om die tegniese proses uit te werk en te hemagtig. is die taal noodwendig, want die woord is die middel waarin die mens se denke, sy logos, sy heheersing van die wêreld waarin hy lewe, uitreik na gestalte en verwesenliking.

Hierly moet verder opgemerk word dat vir die mens as mens soos hy geskape is, geen ander middel denkbaar is watarmee hy sy roeping en taak om die skepping te beheers, te ontgin en uit te bou, doeltreffender en universeler kan volvoer nie: dis bruikhaar vir sy denke, dis drabaar, meedeellaar, oordraaghaar, hestendighaar op verskillende wyses.

Maar hierhy moet beklemtoon word dat dit nie die taal self is wat heheers nie: die taal is die middel waarmee en waarin die beheersing gedoen word. Met die taal maak die mens die dinge wat vir hom "nie-ek” is, toeganklik, ontleedbaar, drahaar, meedeellsaar, want die samehang tussen denke en taal is onlosmaaklik. al is denke nie taal nie en taal nie denke nie. Taal bly altyd middel.

2.

Een van die onderwerpe in die talwetenskap waaroor daar sedert die Grieks. klassieke tyd die meeste gefilosofeer, gespekuleer, gepsigologiseer, gesosiolosigeer e.d.m. is, is: Wat is taal; waar kom dit vandaan of hoe het dit ontstaan en watter doel dien dit, watartoe word dit gebruik? Fn dit is ook reg: dit is vrae waarmee die

3. Vgl. H. van Riessen: „Enkele systematische argumenten voor de uitzonderlijke functie van de taal in de wetenschap" in Correspondentiebladen van de Vereeniging voor Calvinistische wijsbegeerte; XXIII, Mart 1959; bl. 11. 
wetenskap hom besig moet hou. In die meeste van hierdie beskouinge word egter uitgegaan van 'n buite-Skriftuurlike, evolusionistiese, geheel en al humanistiese, antroposentriese standpunt, en ondat ons ons, ook in die beoefening van dic Laalwelenskap, aan hierdie Universiteit onder die gesag van die Heilige Skrif as Woord van God stel, moet ons noodwendig beskouinge en opvattinge afwys wat die Skrif ontken of negeer of wat in stryd met die waarheid wat in die Skrif geopenhaar is. Daarmee word egler nic te kenne gegee dat van buite-Skriftuurlike kant niks nuttigs gelewer word nie, maar ook nie dat die Woord van God 'n bron is waarin wetenskaplike gegewens as wetenskaplike gegewens opgeteken of teorië̈ oor die wetenskap ten heste gegee word nie. Diamond ${ }^{4}$ ) fouteer daarom o.i., selfs met sy voorhehoud, as hy by die hespreking van die teorieë oor die ontstaan van taal nocin "first the theory of the origin of language (if such it can be called) which is contained in the second account of Creation". En hoewel ek my met dic tweede deel van die volgende stelling van Reichling ${ }^{5}$ ) verenig, kan ek dic eerste lid daarvan nie aanvaar nie: „Evenmin als 't voor 't taalkundig inzicht erg voorc!elig is bij Adam te beginnen, verdient het aanheveling bij Darwin aan te vangen". ()ns beweer daarteenoor dat die taalkunde, wat hom ook besig hou met die oorsprong, these en funksie van taal, op geen ander punt as juis hy Adam moet of kan hegin ric, nl. hy die skepping en wese van die mens, hy die aard van sy geskapenheid, by die hesondere verlouding Cod-mens en by die kultuuropdrag en skeppingseën van die mens.

(ns weier daarhy om te aanvaar dat 'n taalopvatting wat op die Heilige Skrif gehaseer is, per se onaanvaarbaarder, spekulatiewer, onlogieser is as enige ander taalheskouing wat tot dusver aangaande die oorsprong, wese en funksie van taal geopper is. ()ns kan verskil oor die interpretasic van hierdie gegewens, maar as waarheid staan dit vir ons bo verdenking.

Daarom wys ons cerstens af elke heskouing wat ontken - regstreeks of hy implikasie - dat die mens as volmaakte, sondelose wese geskep) is, volkome toegerus met alle gawes en vermoëns om sy roeping in die skepping uit te voer. Ons verwerp gevolglik 'n hewering soos die van Diamond'), wat die Bybelverhaal oor die skepping van die mens en die naamgewing van die diere tipeer as „a simple story" en die mens as ,gradually achieving since the beginning of the world his mature mental equipment. He is no longer", gaan hy voort, "centre of the whole universe except in his own eyes. But it can hardly be doubted that this picture of language as originating in the names of things - and especially of the animals, with which the child and the primitive man are so closely in sympathy - constitutes a theory which men are prone to conceive and prone to accept. But what should possess the specchless

4. A. S. Diamond: The history and origin of language; London, 1959; bl. 258.

5. A. J. B. N. Reichling: Het woord; Nijmegen, 1935; bl. 16 .

6. A.w., bl. 259 . 
anthropoid to begin his career as a man by giving names to the animal kingdom or to the few objects around him?" Dit verbaas ons daarom nic dat hy ons aanraai nie : „Let us leave the Bible and turn to the more sophisticated theories of the Greeks and the modern world".

In een lyn hiermee moet ons vervolgens ook afwys die beskouing van Sapir'), wat taal nie kan aanvaar as 'n primêre natuurlike funksie van die mens nie; want so 'n beskouing impliseer dat die mens nie as 'n talige wese geskape is nie, dat hy n:ie van die begin af kon praat soos hy van die begin af kon loop nie. Die mens is, byvoorbeeld, volgens Sapir se opvatting, so gebou dat hy moct loop, en hy sal ook lnop, selfs al sien hy nooit 'n medemens loop nie. Die bene en spierstelsel van die mens, so betoog hy verder, is primër gemaak om vir loop gebruik te word, maar die spraakorgane is slegs sekondêr vir taal bedoel. Loop is 'n aangebore biologiese funksie, ,het spreken echter is een menschelijke werkzaamheid die zonder aan te geven grenzen variëert van de ene sociale groep tot de andere, omdat het een zuiver historische erfenis is van de groep, het product van een langdurig sociaal gebruik". Loop is 'n organiese, instinktiewe funksie; praat is 'n nie-instinktiewe, 'n aangeleerde, 'n ,sociale" funksie. Vir hom is taal 'n kultuurproduk, hoewel hy dit die oudste kultuurbesit van die mens ag, ouer as die kuns, vuurboor, bewerking van klip, ens. „Ik ben geneigd te geloven", aldus Sapir ${ }^{8}$ ), dat het ontstaan van de taal zelfs ligt vòor de allereerste ontwikkelingsfasen van materiële beschaving, ja, dat deze eerst mogelijk werden nadat de taal, het instrument van de betekenisdragende uiting, zelf gevormd was".

Ons moet ook afwys elke beskouing wat by die mens, ook ten aansien van die taal, meer of iets ander sien as 'n ontwikkeling in die soort self. Die mens is nie die uitkoms van 'n langdurige ontwikkeling oor baie soorte nie maar is as mens geskape. Gevolglik moet die mens ook nie met die dier vergelyk word om tot helderheid oor sy wese te kom nie: hy het met die dier wesenlik niks gemeen nie.

Daarom wys ons ook van die hand alle teorieë wat die oorsprong en ontwikkeling van taal by die dier of in die diergeluid soek, soos o.a. weergegee deur Gardiner, wat sê: „True, the ultimate basis must be the involuntary cry of the individual animal"'), of in die ekspressiewe gebaar en klank, in geluide wat ontstaan het deur kragtige beweging van die arms (soos in 'n kapheweging) en die gevolglike sametrekking van die spiere van borskas en strottehoof ${ }^{10}$ ), in die minnelied, wat sou

7. Edward Sapir: Language. An introduction to the study of speech; Nederlandse vertaling deur A. L. Slöteman: Wat is taal?; Amsterdam, 1949; bl. 1-2.

8. Ibid., bl. 24. Hierin is ek dit met hom eens.

9. Alan H. Gardiner: The theory of speech and language; Oxford, 1932; bl. 19.

10. Vgl. Diamond: a.w., hfst. 17. Hieruit sou rudimentêre „woorde" soos bá, dá ens. ontstaan het. 
herinner aan geluide êrens tussen die van 'n verliefde kat en die nagtegaal ${ }^{11}$ ).

Ons ontken dat taal as kommunikasiemiddel tussen mense ontstaan het en primêr as sodanig bedoel en benodig is, dat taal tot stand gekom het uit 'n behoefte aan hulp ${ }^{12}$ ) of primêr bedoel is om te wees ,the instrument by which human behaviour in society is initiated and fostered" ${ }^{13}$ ) of as blote kontakmiddel met die omgewing moet dien ${ }^{14}$ ) of in eerste instansie bedoel is en gebruik word "to influence the conduct of others"15).

Laastens ontken ek ook dat taal in eerste instansie vir die mens middel tot selfvergestalting en selfverwesenliking is, o.a. Croce beweer ${ }^{16}$ ).

\section{3}

Hierteenoor stel ons dat die mens die hoogste skepsel van God is, geskape na die beeld en na die gelykenis van God, volmaak en sondeloos geskape, en dat hy in sy geskapenheid en geroepenheid as mens so toegerus is dat hy sy volle roeping koninklik, profeties en priesterlik kan vervul. Dat die mens na die beeld van God geskep is, sluit ook in dat hy ware kennis gehad het, ,en niet het minst door die ware kennis gaf God hem heerschappij over alles"17).

Hierin en hiertoe is ook die taal as middel gegee. As die mens dus die diere name

11. O. Jespersen: Language: its nature, development and origin; London, 1922; bl. 434: „Language was born in the courting days of mankind; the first utterances of speech I fancy to myself like something between the nighty love-lyrics of puss upon the tiles and the melodious love-songs of the nightingale".

12. Diamond: a.w., bl. 12. Dlamond kom bale na aan dle waarheid as hy sy bewering in hierdle verband nader kwalifiseer met die woorde: „for the purpose of controlling his environment". (Ek onderstreep.) Die basiese fout in sy beskouing is dat hy die beheersing net in die kommunikatiewe gebrulk van taal vind.

13. Dewey, gesiteer deur Diamond: a.w., bl. 12.

14. Révész: The origins and prehistory of language; London, 1956; bl. 66 . Op die oog af lyk sy uiteensetting hier in hoofsaak aanvaarbaar: "On the basis of his inherited predisposition every human being must acquire his language by contact with his environment and to a degree recreate it", maar as hy op bl. 86 uiteensit wat hy onder kontak verstaan, nl.: ,The word ,contact' slgnifies the innate tendency of social animals (slc!) to approach one another, establish rapport, co-operate and communicate. It is a universal princlple of life for individuals belonging to social groups", dan blyk daarult dat hy ook kommunikasie as basiese uitgangspunt aanvaar.

15. Gardiner: a.w., bl. 19. Vgl. ook L. Bloomfleld: Language; London, 1950; bl. 22: „Language enables one person to make a reaction when another person has the stimulus".

16. Vgl. Gardiner: a.w., bl. 21. Ook J. Woltjer verklaar in sy rede by die oordrag van die rektoraat van die V.U. In 1908: ,Het woord is in zijn wezen middel van uiting, ultdrukking, openbaring" (Het woord, zijn oorsprong en zijne uitlegging; Amsterdam, 1908; bl. 30).

17. J. Woltjer: „Ideëel en reëel” in Verzamelde redevoeringen, I; Amsterdam 1931; bl. 181 
ge屯 $^{18}$ ), is hy nie besig met kinderlike en selfs kinderagtige spel, soos Diamond ${ }^{19}$ ) dit voorstel nie, maar hy staan ten volle in sy roeping om die skepping te beheers met die middel waarmee hy deur sy Skepper loegerus is en op die wyse waartoe hy geskape is, nl. deur die woord. Sikkel ${ }^{20}$ ) druk dit só uit : „De geest, het woord des menschen, is het hoogste scheppingswerk $\mathrm{Gods}^{21}$ ), en door het woord moet de geest des menschen vormen, de wereld regeeren en de schepping bewerken".

Sikkel druk dit verderop (bl. 161-163) nog duideliker en omvattender uit: God se verhond, sê hy, het in Adam gestaan, Aan hom is die woord, die taal, „en daarmee de heerschappij" geskenk. Die perikoop Gen. 2 : 18.25 is baie helangrik daarin dat hier voorkom die mededeling van "de verbondmatige ordening der verhoudingen door den HEERE, der verhoudingen tusschen den HEERE en den mensch, en tusschen den mensch en de schepping; hepaald ook nu tusschen den mensch en het gedierte, en tusschen mensch en mensch". Die diere word deur die Here aan die mens oorgegce „en door diens geest in diens woord beheersch". (Ek onderstreep.)

Dat Adam die diere name moes gee, sê Taljaard ${ }^{22}$ ), ,sou voorwaar 'n moeilike taak gewees het, as God nie 'n henoembaarheidsaspek in die aardse skepping gelê het wat deur Adam henoem moes word nie. Adam het dus nie slegs 'n linguale funksie ontvang nie, maar ook 'n vermoë om te kan onderskei: hy kon die licnoemhaarheid van die verskillende diere onderskei en hulle daarvolgens benoem". Vir die beheersing deur die taal is hierdie benoemhaarheidsaspek en die onderskeiding van die grootste hetekenis. Maar ook die omgekeerde is van helang. Sonder die "linguale funksie" sou benoembaarheid geen sin gehad het nie.

Dit is dus duidelik dal die mens hier nie in die eerste plek met selfvergestalting mn selfverwesenliking hesig is nie maar met roepingswerk, uitvoering van sy beheersingstaak wat aan hom opgedra is. En omdat Cod, hy wie die ewige Woord is, deur die woord van sy mond die skepping in aansyn geroep het, kan die mens as beeld van God met die woord uit sy mond benoem en beheers, die geskape skepping vir sy beheersingsdoel weer omskep tot woord.

Hiermee stel ek my egter nie heeltemal op dieselfde standpunt as Cuarini ${ }^{23}$ ) nie. In die afdeling „Der Wortcharakter der Dinge” gaan hy ook in op die verband

18. Gen. $2: 19,20$.

19. A.W., bl. 259 .

20. J. C. Sikkel: Het boek der geboorten; Amsterdam, 1923; bl. 161. Ek onderstreep.

21. Bloomfield (a.w., bl. 29) het ook baie hoë agting vir die taal, maar dan gesien as 'n prestasie van die mens, as hy sê dat die bemagtiging van spraak deur die kind in sy eerste par lewensjare ,is doubtless the greatest intellectual feat any of us is ever required to perform".

22. J. A. L. Taljarar: "Die mens, die liefde en die sedelike" in Koers; XXIII, 6 (Junie 1956); bl. 296.

23. R. Guarini: Welt und Person; Wurzburg, 1955; bl. 146. Ek onderstreep. 
tussen woord en skepping, maar dan stel hy die mens in 'n spanning tussen God en wêreld en sê: „Der Mensch ist der zum Hörer des Welt-Wortes Bestellte. Er soll auch der Antwortende sein. Durch ihn sollen alle Dinge in der Form der Antwort zu Cott zurückkehren".

Sikkel ${ }^{24}$ ) stel hierdie saak in 'n ander perspektief : nie as antwoord van die mens nie maar in die eerste plek deur die woord van Gor self keer die geskape dinge tot Hom terug, maar ook ,in hel noemen der schepselen moest de mensch Gods zich de gesproken woorden, de gedachten Gods, geestelijk bewust worden en ze uitspreken, ze tot (jod in het menschenwoord doen terugkeeren... De mensch moest in zijn woorden het Woord vertolken, spreken, belijden, Gorls Naam uitroepen ... Gods verlorgen herloelen, het einde zijner Schepping, gelijk dit in die Schepping, zij het omhuld, ligt uitgedrukt, zou zoo het hewust eigendom van den mensch geworden zijn". Hierin wortel dan ook die Christelike wetenskapsbeoefening: die soeke na, die ontgimning, onthulling, heheersing van die wonders in die skepping van God deur en in die wonder van die woord.

Baie mooi (lruk ook Woltjer dit uit ${ }^{25}$ ): „Het woord des menschen is alleen daardoor te verklaren, dat hij is van Gods geslacht, geschapen naar het beeld van Hom, hij wion het woord was, eer het als scheppingswoord aller dingen zijn wezen hepaalde (dic ,henoemlaarheidsaspek" hierho genoem - H.V.); die door het Woord verlicht een iegelijk mensch, wanneer hij komt in de wereld, en hem bekend makkt wat zijue gedachten zii (Amos 4: 13); die Zijn woord legt in den mond van proleten en apostelen en als geschreven woord doet blijven tot aan het einde der eeuweı". Fin elders ${ }^{26}$ ) sê hy : „Adam moet (met die naamgewing van diere), zouden we kunnen zeggen, zijn proefstuk leveren. Fn dat proefstuk bestaat eigenaardig juist daarin, dat hij moet toonen, dat de logos in hem workt naar de gelijkenis van den Logos zijns Scheppers".

So gesien is die mens se woord in eerste en laaste instansie van God se woord athanklik, ell só reik die woord van die mens uit God gehore in beheersende funksie (nie antwoordende nie) van skepping tot herskepping, oor verduistering as gevolg van sondeval ${ }^{27}$ ) en vloek deur die verlossing en versoening in Christus, die vleesgeworle Woord, heen.

24. A.w., bl. 107-108.

25. J. Woltjer: Het woord, aijn oorsprong en zijne uitlegging, bl, 61.

26. "De wetenschap van den logos" in Verzamelde redevoeringen, bl. 25.

27. Die feit van die sonde mag in ons taalbeskouing nie geloën of verontagsaam word nie: dit het ' $n$ hele kentering in die mens teweeggebring en daarom ook in sy vermoë om die dinge te ken; dit het gevolglik die vermoë om die dinge te beheers vertroebel, en dit word in die taal gereflekteer. In ons soeke na vak- en vakwetenskaplike terminologie en ander woorde, in die noodsaaklikheid om taalburo's en taaladviseurs te benoem, in woordeboek en woordelys word die deurwerking van die sonde geopenbaar maar tree ook meteen die stryd teen die sonde aan die lig: dis 'n ultreik na suiwere beheersing in dle woord. 
En omdat God die dinge geskep het met bepaalde wesendhede, bepaalde funksies, bepaalde verhoudinge, hoedanighede, in bepaalde omstandighede, getal ens. en die mens na sy beeld geskep het, het die mens kemnis en bewussyn van die dinge, wat prof. Labuschagne die logos ${ }^{28}$ ) noem en Woltjer die gewaarwording ${ }^{29}$ ); en omdat die mens bewussyn van die dinge, die "logos", die gewaarwording het en steeds van meer en meer dinge verkry, het hy en maak hy woorde vir die dinge in al die kategorieë van die bewussynlike, van die logos, die gewaarwording. Hy omhul en omklee sy logos of gewaarwording met die woord. In die verlossing wat dit in die woord vind, lê die beheersingsfunksie van die mens met die taal as middel.

Hieruit sal dit blyk dat dit beter is om die woordsoorte nie te sien as ervarings. kategorieë nie maar as beheersingskategorieë.

God, wat zelf nie aan ruimte en tyd gehonde is nie, het egter sy skepping in ruimte en tyd gestel, en binne die dimensies van ruimte en tyd heweeg die mens en voer hy sy heheersingsfunksie uit en beweeg ook sy taal. Maar dit lê ook aan die wese van die taal dat dit, soos die mens se gees, geskik is om tyd en ruimte te oorspan, om oor tyd en ruimte heen te reik. Hierin hereik die taal wat Koki in Raka van Van Wyk Louw sy verblinde stamgenote in die simboliese taal van die poësie toevoeg:

\section{Ken Raka, hy}

die sterk dier, ons fyn, fyn net

van die woord, waarmee ons blink en vet

visse uit haie waters haal?

In hierdie hele siening van die ontstaan en funksie en gehruiksmoontlikhede van taal soos dit tot dusver gestel is, is niks toevalligs en ook niks van verlygaande of so min belang dat ons ons net 'n skouerophaling daarvan kan afmaak en ons na ander, meer gesofistikeerde teorieë kan wend nie.

Daarom aanvaar ek ook nie dat die spraakorgane maar net sekondêr vir taal henut word nie: hulle is net sowel daarvoor as vir ander doeleindes geskep. Die long is minstens net soseer vir spraak danr as om kos in dic mond rond te rol; die lippe, die tande en tandwortels, harde en sagte gehemelte, huig en neuskanaal ${ }^{\text {sn }}$ ) word nie maar toevallig vir spraak gehruik nie; stemband en oor bring nie maar toevallig klank voort en verneem klank nie; die hepaalde hreinsentrum wat taal en spraak beheer, het ook nie maar tocvallig in die mens tot stand gekom of daar ontwikkel nie. Die mens is kragtens die wyse waarop hy geformeer is, 'n talige wese, en kragtens hierdie geskapenheid kan hy geen ander iniddel as juis die taal hê of gebruik vir die spesifieke doel waartoe taal dien nie, nl. as middel om die

28. T.W.K., Oktober 1957, bl. 84.

29. "Ideëel en reëel" in a.w., bl. 194.

30. Dis nogal opvallend dat een van die eerste klanke wat die mens as baba gebruik, 'n nasaal is: $m$, terwyl die $n$ reeds betreklik vroeg sy verskyning maak. 
skepping te beheers, middel waarmee die mens die beheersing in homself uitvoer en uitreik na buite.

Gesien die feit dat die mens volmaak geskape is - nie as kind nie en ook nie as dier of halfdier nie - en gesien die feit dat God onmiddellik met hom gepraat het, moet ons aanvaar dat die mens volledig toegerus was om te hoor, te interpreteer, te verstaan en self woorde te vorm en uit te spreek - getuie die natamgewing van die diere.

Daar hestaan verskil van mening oor die vraag of die mens "met taal en al” geskape is dan wel of hy self sy taal gevorm het. Aalders") meen: „Het is... omjuist hier (Gen. 2 : 19,20) de voorstelling te vinden, dat de mensch zijn eigen taal zou gemaakt hehben. Integendeel de mensch maakt gebruik van een taal die er reeds is... Wij zullen moeten aannemen, dat de taal met de schepping van den mensch zelf gegeven is". Aalders het dit elders ook beweer ${ }^{32}$ ) en daaraan toegevoeg: ..De taal behoort tot het wezen van den mensch, en door de taal is de mensch van het dier onderscheiden; zooals elk dier zijn eigen geluid bij zijn schepping van God zall hebhen ontvangen, moet ook de mensch de gave der taal, gelijk alle andere vermogens dic hem de Schepper verleend heeft, bij zijn schepping zelve verkregen helhben". Vir Aalders lê origens in die naamgewing van die diere nie die beheersingsfunksie deur middel van die laal nie, maar die mens moes daardeur eers tot die hepaling van die wese van die diere kom en vervolgens die onderskeid tussen mens ell dier deurskou. En daarvoor maak hy gebruik van „de hem door God gegeven taal"'s3).

Ilierteenoor staan die uitspraak van Sikkel ${ }^{34}$ ) dat die mens die woorde wat Cod tot hom gespreek het, in sy gees bewar het, "maar in diezelfde taal formeerde nu de mensch woorden. Die taal bloeide in den mensch op en uit". En by hierdie heskouing sluit aan Woltjer se bykans poëties geformuleerde verklaring $\left.{ }^{39}\right)$ : „In den logos van den mensch spiegelde, in creatuurlijke mate, zich zuiver af de Logos, het Woord, dat in den beginne was bij God, door hetwelk alle dingen gemaakt zijn. De logos alleen kent den Logos".

Maar of die een of die ander beskouing juis is - self voel ek meer geneig tot die standpunt van Sikkel en Woltjer - vind ek in hierdie Skrifgegewe geen grond om le veronderstel of te aanvaar dat die taal van die mens oorspronklik power, armlik, gebrekkig was en net uit krete om hulp of uit liefdesbetuigings kon bestaan

31. G. Ch. Aalders: Het boek Genesis opnieuw uit den grondtekst vertaald en verklaard; Kampen, 1933; bl. 124.

32. Idem: De Goddelijke openbaring in de eerste drie hoofdstukken van Genesis; Kampen, 1932; bl. 333.

33. Ibid., bll. 333, 334 .

34. A.w., bl. 161. Ek onderstreep.

35. „De wetenschap van den logos" in a.w., bl. 24. 
het nie $\left.^{36}\right)$. Inteendeel, ek is daarvan oortuig dat hierdie taal goed, volmaak, volkome adekwaat was, sodat die sondelose mens, wat suiwer en finaal geken het, ook suiwer en finaal kon verwoord. Die taal wat Adam gelesig het, moet 'n haie suiwer taal gewees het, waarin die heerlike, volmaakte skepping, waarvan God self gesien het dat alles wat Hy gemaak het, gocd was, ,wit nopgekelk en suiwer soos 'n hlom" gestaan het. Omdat tussen ons en hierdie taal die verduistering deur die sonde staan, is dit vir ons moeilik om ons hierdie taal voor te stel. Of dit ingewikkeld was, sinteties-kompleks? Watter taal is, op die keper beskou, ingewikkeld vir wie dit gebruik?

Iliermee is dan reeds gesê dat die taal nie 'n ontwikkeling uit die diergeluid is of kan wers nie maar spesifiek menslik, omdat die mens so geskape is maar ook omdat hy 'n roeping en opdrag gehad het om in en met die taal uit te voer: behecrsing, hewerking en hewaking van die skepping van God. En dit hou in soos reeds gesê, dat die taal nie in die eerste plek middel tot selfverwesenliking en selfvergestalting is nie: dít is uitkomste van die heheersingsfunksie van die mens met die taal as die middel.

Ilieruil moet ook gekonkludeer word dat taal nie in die eerste plek kommunikasiemiddel is nie en ook nie in eerste instansie uit die maatskappy voortgekom het nie. Uit die chronologie van Genesis 2, nl. uit vs. 20, hlyk dat die mens hom van sy eensaamheid bewus geword het juis in die uitvoering van die opdrag om die diere name te gee. Met ander woorde, Adam was talig werksaam voor die skepping van liva. Dit is daarom duidelik dat die mens sy taal nie eers as verkeersmiddel gehruik nie, maar hy gel)ruik dit om sy beheersingsopdrag uit te voer, 'n beheersing wat eers individueel moes geskied en eers daarna - maar ook nie altyd nie gemeenskaplik. Ek wil selfs heweer dat alle heheersing - ook in die taal en ook vandag nog - by die individu begin, deur die individu woord word, ,getaal”, ,taal gemaak" word en daarna gemeenskaplike besit word of nie. Ook Van Riessen wys daarop ${ }^{37}$ ) dat dit foutief is om taal en wetenskap as wesenlik kommunikatief te heskou. Die mens is talig hesig ook huite kommunikasie om. "Zowel de taal als de wetenschap (zijn) mogelijk en (kunnen) zinvol hestaan zonder de sociale relatie."

Dit word geillustreer deur die volgende voorval. Ons dogtertjie het grootoog die huis hinnegekom en naan gesê. Wel het sy hiermce iets aan ons meegedeel - wat ons toe nie verstaan het nie - maar voordat sy dit aan ons kon meedeel, moet sy eers in haarself en vir haarself uitgemaak het dat dit wat sy gesien het (later het geblyk dat dit 'n vliegtuig was), 'n naan is. Voordat die mens 'n woord vir mede. deling kan gehruik, moet hy dit eers self verwerf, in homself besit: of deur dit self te vorm of deur dit te hoor, niteindelik van iemand wat dit self gevorm het.

36. Dit ook in teenstelling met wat Révész beweer (a.w., bl. 61 e.v.), o.a.: „Earliest speech must have been exceedingly simple and confined entirely to essentials" (bl. 62).

37. A.w., bl. 11 . 
Natuurlik is daar, ten spyte van materiaal wat gedurig uitsif en wegval, 'n altyd groter balans wat van geslag op geslag oorgedra word - wat deel is van die seën wat ons in taal het, soos weldra sal blyk - maar alle woorde wat bestaan (of dit nou 'n neologisme soos eweskerp is of die woord in buitengewone verband en sin iI digterlike vondste soos die van Watermeyer:

$$
\begin{aligned}
& \text { Ek kelk die sonlig in my keel } \\
& \text { en rym die ronde bessie ryp, }
\end{aligned}
$$

dan wel of dit 'in ecue-oue tradisionele woord soos broer is), ontstaan nie gelyktydig hy alle individue in 'n spraakgemeenskap nie maar het hulle oorsprong by 'n individu. Selfs die feit dat 'n woord soos sputnik oor die hele wêreld feitlik gelyktydig lekend geword het, loënstraf die bewering nie: hy het nogtans sy ontstaan by 'il enkele Rus.

'Taal is dus nie in die eerste plek 'n sosiale verskynsel nie maar ' $n$ individuele lycheersingsmiddel, 'n middel waarmee eers die individu en daarna die gemeenskap sy lewensuniversum beheers. Daarom span Gardiner die kar voor die perde as sy heweer "1): „If language has proved necessary for thought of an abstract kind and for intellectual sclf-expression, that function is secondary and a by-product, so to speak; surely the primary function of speech was to facilitate co-operation in such natters as could not be indicated by mere pointing or gesticulation". Wat die voorstanders van die sosiale en hulpinroepende funksie van taal as sy ontstaansgrond nêrens oortuigend verklaar nie, is dít: As die mens so toegerus was dat hy kon praat en in sommige gevalle hulp deur middel van taal kon inroep, hoekom sou hy dit dan net in sekere gevalle doen, nl. waar hy dit nie met gebare kon doen nie? En, lowendien, hoe moes hy die woorde gebruik het as hy hulle nie eers in homself gevorm het nie?

Die erkenning van die primaat van die individuele aspek van taal teenoor die sosiale en kommunikatiewe hou ook in dat die finale betekenis van die woord nie hy die hoorder nie maar hy die spreker berus. Daarom kan ek nie met Diamond ${ }^{39}$ ) saamslem nie waar hy beweer: "Though a speaker may choose to employ those scunds (wat hy uitspreek) with a view to produce a particular meaning, the effective meaning to those sounds is in the mind of the hearer rather than the speaker". Watter skade hierdie opvatting die wetenskapsbeoefening en die oordra van eksak wetenskaplike kennis kan herokken as nie die leermeester se bedoeling nie maar die leerling se opvatting deurslaggewend is, behoef geen verdere betoog nie.

Ons ontken egter nie die kommunikatiewe bruikbaarheid en gebruiksmoontlikhede en funksie van taal nie; ons ontken net die primaat daarvan. „Het voorrecht van te kennen is allereerst een persoonlijk aangelegenheid, een persoonlijk rijker worden aan kennis. Dat het onze roeping is dit voorrecht ook met anderen te

38. A.w., bl. 21

39. A.w., bl. 9. 
delen is daarmee niet in strijd", aldus Van Riessen ${ }^{40}$. Vanselfsprekend - en dit is ook Van Riessen se hele betoog - is die taal in albei gevalle essensieel.

Dat taal as spraak meedeelbaar is, sosiaal, intermenslik bruikbaar, verstaanbaar en interpreteerbaar, is wel sekondêr maar nogtans hoogs belangrik. God het in sy wvsheid by die skepping geweet en gewil dat die mens nie alleen sal wees nie. "Wees vrughaar en vermeerder en vul die aarde", is telkens sy bevel aan die mense. Binne die kader van die mens se hele aktiwiteit is die oordraagl)aarheid, die uitwisselhaarheid, die „verdiskonteerbaarheid" van taal van onvervangbare waarde vir die beheersing van die skepping. Nêrens kom dit duideliker uit as in die spraakverwarring by Bahel nie. Toe die mense hulle beheersingstaak nie op God se wyse wou uitvoer nie, nie die aarde wou bevolk en onderwerp soos God hulle beveel het nie maar die beheersing op eie wyse wou uitvoer en vir hulleself naam wou mak, het God hulle na sy wil geluig deur hulle beheersingsmiddel nutteloos te maak vir hulle doel: Hy het hulle spraak verwar. Daarna het hulle oor die hele aarde versprei ${ }^{41}$ ). Vir gemeenskaplike beheersing net soos vir die individuele is taal en spraak onontbeerlik.

Vandaar dan ook dat taal binne 'n hepaalde gemeenskap en bepaalde beheersingsveld 'n hepaalde gemeenskaplike vorm $\mathrm{kry}^{42}$ ), hoewel daar velerlei individuele en gewestelike afwykings is. En hoewel taal nie primêr uit die gemeenskap opkom nie, het die kommunikatiewe sosiale gel,ruik daarvan 'n groter draagwydte en 'n wyer heheersingsgebied - ook vir die individu - daaraan gegee, waardeur dit selfs vinniger kon groei: die ervarings- en behecrsingsgebied en gevolglik ook die woordeskat van 'n gemeenskap is noodwendig groter as die van 'n enkeling.

Nogtans is kommunikasie en die hoorder nie noodsaaklik vir hierdie oopgaan van die taal soos Gardiner ${ }^{43}$ ) beweer nie: "Thus at every stage the mutual interaction of speaker and listener is presupposed". In die grond van die saak is dit nie 'n behoefte aan meedeling wat die taal en spraak vorm nie, maar die individuele leheersing van die dinge. Kommunikasie is 'n moontlikheid wat voortgekom het uit die aard en wese van taal as beheersingsmiddel maar is nie as primêre noodwendig. heid daarin gegee nie. En selfs vandag nog gebruik die mens veel meer taal buite kommunikasie om as daarin. Dis juis in 'n groot mate hierdie siening van talal as in eerste instansie verkeersmiddel wat aanleiding gegee het tot die soeke na

40. A.w., bl. 11.

41. Vgl. vir hierdie hele gebeure, ook vir die taal by Babel, W. Venter: Die plek van Gen. 11 : $1-9$ in die Ou-Testamentiese openbaringsgeskiedenis; ongepubl. Th.M.-skripsie, P.U. vir C.H.O., 1954.

42. F. J. Labuschagne: a.w., bl. 89: „Die woord en taal is dus na sy oorsprong en wesc en in bepaalde funksies personisties-indiwidueel, na sy vorm en in bepaalde funksies binne 'n bepaalde gemeenskap sosiaal". (Kursivering aldaar.)

43. A.w., bl. 20. As dit die geval is, het die monnike van die Trappisteorde nie taal nie, en dan is kontemplasie vir hulle onmoontlik. 
ooreenstemmende aspekte met die diergeluid. Indien die wese van taal as beheersingsmiddel ingesien is, sou waarskynlik nie na raakpunte met die diergeluid gesoek gewees het nie.

Dit is verder ook duidelik dat die geskiktheid van die taal om kommunikatief gehruik te word die heheersing van die skepping in lelangrike mate bevorder het. Dil naak die oordra van ervarings en bevindinge moontlik, waardeur eerstens 'n licle gemeenskap in die ervarings en bevindinge van enkelinge kan deel, en tweedens kan ervarings en hevindinge van vorige geslagte aan volgendes meegedeel word. Dat die beheersing van die skepping hierdeur bespoedig is en universeler geword het, lehoef geen letoog nie, ook nie dat dit die vordering van die wetenskap ten goede gekom het nie: dieselfde ontdekkinge en bevindinge hoef nie oor en oor gedoen te word nie, want hulle word in die taal van die een navorser na die ander en van die een geslag na die ander oorgedra. Sonder die taal om dit in te lestendig en oor te dra sou die heheersing minder kontinuïteit en minder universa. liteit gehad het, en die algehele ontginning en beheersing van die skepping sou reel stadiger geskied het.

Die beheersingsvaardigheid van taal word ook verhoog daardeur dat die moontlikheid van oordrag van taal in kommunikatiewe gebruik haas onbeperk is, en daar is geen ander middel wat soveel oordragghaarheidsmoontlikhede as die taal liet nie. Dit stel die mens in staat om die wêreld en sy volheid in sy geheel te beheers, 'n beheersing wat sonder hierdie moontlikhede van oordraagbaarheid beperk, lokaal gebonde sou gehly het. Die leheersing het juis so universeel geword as gevolg van die bestendigings- en oordraagbaarheidsmoontlikhede van taal.

Vir homself kan die mens dit op skrif stel en so bestendig en deur dit op skrif te stel desverkiesend toeganklik maak vir ander wat na hom kom. In kommunikatiewe gel,ruik kan taal in gesproke vorm oorgedra word: regstreeks, per boodskapper of gesant, diktafoon, grammofoon, telefoon, radio, klankprent ens. In geskrewe vorm kall dit geskied : per brief, proklamasie, koerant, lydskrif, boek, mikrofilm, ideogram, spykerskrif ens. Dit kan ook deur ander luitetaallike middele oorgedra word: vingertaal, snelskrif en die morsekode per telegraaf en heliograaf, deur vlae (semafoor) ens.

Al hierdie middele is moontlik gemaak deur die kommunikatiewe bruiklaarheid van taal, maar dit het terselfdertyd die moonllikhede van kommunikasie deur taal onhepaallıaar veroroot. Matar hierdie moontlikhede van kommunikasie is al weer nie afgelei nit 'n beheersingshehoefte van die maatskappy nie, maar dit is die gevolg van die uilvoering van die beheersingsopdrag deur die individuele mens. In die grond lê altyd die feit: die mens het vir taal nie 'n medemens nodig nie, want hy heheers sy wêreld deur sy eie taal. Dat die taal wat hy hesig, in ooreenstemming is met die taal van duisende en miljoene ander mense, is sekondêr maar ook nie insidenteel of toevallig nie: só het God dit gewil, en die verwarring by Babel loënstraf dit juie. 
Daar is nie 'n treffender algemene aspek van taal as sy universaliteit nie, aldus Sapir ${ }^{44}$ ). Daar is nie 'n volk bekend wat nie 'n eie, volledige ontwikkelde taal liet nie. Maar hoewel elke mens binne 'n bcpaalde spraakgemeenskap en elke spraakgemeenskap as sodanig binne sy eie grense 'n eie tal het, is dit ook duidelik dat hierdie taal - sonder bevrugting en verryking van buite - nie meer bestryk as die gebied warin hy hom bevind nie. Met ander woorde, die mens se taal word begrens of ingepcrk deur die milieu wat hy hewoon, warin hy heweeg en wat hy moet beheers. Selfs in die vlugte van sy fantasie - getuie die kuns deur die eeue - bly hy in sy voorstellinge en taal gebonde aan die dinge wat hy beheers. Afrikaans het vanweë sy isolasie in die linneland oor die drumpel van hierdie eeu gekom as 'n suiwer hoeretaal, waarin die land en die landelike in elke opsig versink het, woord geword het. Maar in die afgelope 60 jaar het dit onder inwerking van laktore van huite 'n onvergelyklike kentering ondergaan: met die deurbreking van die isolasie en die haie nuwe raakpunte na buite wat daar gekom het, veral ook met die sogenaamde industriële rewolusie, wat vandag nog aan die gang is, het dic hehecrsingsgehied op alle vlakke geweldig uitgehrei, en die taal het daarmee tred gehou. Hierdie feit blyk ook dauruit dat die woordeskat van die Boesman in haic helangrike opsigte verskil van die van die bewoner van die moderne grootstad: die beheersingsgehied verskil $\left.{ }^{45}\right)$. Mar in alle gevalle bly die taal van taalmaker en, deur hom, van gemeenskap toereikend om die verskillende beheersingsvlakke te dek.

In die mate en wyse van heheersing asook in die objek wat in die taal beheers word, is die betekenis van die woord vir die mens bepaal ${ }^{46}$ ). Dit blyk onder andere daaruit dat die woord lam nie in die Eskimo's se Bybel voorkom nie: in lam is in hulle wêreld nie hekend nic. In hulle Bybel word dit vertaal met „kleintjie van 'n rol,". En Ulfilas vertaal Markus 1 : 6: „En Johannes was gekleed met kameelhare", in sy Gotiese Bybel met "Wasub-ban Iohannes gawasiha laglam albandaus", wat deur teksuitgewers deurgaans as "hare van 'n kameel" vertaal word. En tog meen ek in ulbandus die ekwivalent van olifant te sien. (Sou Ulfilas hier die mammoet in gedagte gehad het?) Ewe-eens word wat in die Afrikaanse Byleel met Mammon vertaal word (bv. Luk. 16 : 9), in die Gotiese Bybel met faihubraihn(s?) weergegee - letterlik "'n gedrang van vee"!

44. A.w., bl. 23.

45. Nadat ek dit geskryf het, het my ter hand gekom 'n artikel van Geschiere: „Playdoyer pour la langue" in Neophilologus; XLV, 1; Januarie 1961, waarin hy op bl. 26 die volgende skryf: „Un idiome papou qui suffit à la communauté vivant au milieu de la forèt vierge, serait absolutement insuffisant pour qui vivrait dans un milieu intellectuel de l'Europe occidentale. Et inversement les ressources du francais demanderaient une sérieuse adaptation pour rendre possible la vie d'une communauté francaise dans la forêt vierge".

46. Gardiner praat in hierdie verband ook van ,area of meaning" (vgl. a.w., bl. 36-37). 
So word taal heperk deur die mens en deur die tyd en die ruimte wat hy heheers. Vir my, hyvoorbeeld, is 'n bossie iets skadeliks wat in my tuin opkom waar ek dit nie gesaai het nie en wat die groente, wat ek wel gesaai het, verdruk en lenadeel. Fk weet ook van die Karoobossie en dal die skape in die Karoo dit vreet, maar ek kan hom nie uitwys nie. Die Karooloer ken egter die bossie, en dit is die leeftog van sy skape en gevolglik deel van sy welvaart, en vir hom is daar goeie en skadelike bossies. Vir ' $n$ plantkundige is 'n bossie 'n plant wat ondersoek kan of moet word na wortelstelsel, stingelvorm, hadvorm, blaarstand, blom, bloeiwyse en vrugvorm ens. en wat benoem en geklassifiseer moet word; vir die kruiedokter is die geneeskundige waarde al dan nie van 'n bossie van belang.

Hats is vir menigeen net "n woord uit sy repertoire sonder dat hy ooit 'n werklike haas gesien het; vir 'n boerseun met 'n hond is haas 'n lewende realiteit met baie moontlikhede; vir die naturel met 'n maer windhond lusteloos agter sy hakskene heteken die haas voedsel as die hond dit kan inloop; vir die groente- en graanhoer is haus 'n wesenlike bedreiging, en as ek sê iemand is 'n haas, het dit heeltemal verwyderde, oordragtelike hetekenis wat met 'n lewende has weinig te make het. Vir die dierkundige is dit iets heel spesifieks, wat anatomies ondersoek moet word en dikwels nie meer die naam haas dra nie; vir die dobbelaar by die hondewedren is dit 'n springende lapding met honde op sy hakke, dog die haas is nie van belang nie, maar Opperman skep dit on tot simbool van die deur sy gewete opgejaagde mens:

() week na week gebonde

'n huts in die ovale kring

en agter my ses honde (,, Ballade van die grysland").

Dis duidelik dat die verskuiwing linne die ,area of meaning" van die betekenisvlakke van die afsonderlike woord die beheersingsmoontlikheid van die taal haic uilbrei. In die alledaagse gebruik moet 'n woord om bruikbaar te wees 'n hetekenisgelied hê wat so wyd moontlik is. Sapir ${ }^{47}$ ) wys daarop dat in die woord huis saamgctrek is al die inlrukke wat die gebruiker daarvan het, asook die indrukke wat ander gebruikers daarvan het. Want, sê hy, ,als het simbool ,h u i s'... slechts betrokken was op het enkele heeld van een bepaald huis dat men eens gesien hal,... (is het) van stonde af aan evident dat taal in deze zin weinig of geen waarde zou hehhen voor onderlinge verstandhouding”. Fin (Gardiner ${ }^{48}$ ) beweer

47. A.w., bl. 11-12: „De afzonderlijke indruk die ik heb ondergaan van een bepaald huis moet worden geidentificeerd met al mijne andere indrukken daarvan. Vervolgens moet mijn veralgemeende herinnering aan, of mijn ,notie' van dit huis worden samengesmolten met die noties welke alle andere personen daarvan hebben gevormd. De op zlchzelf staande ervaring die ons uitgangspunt is geweest, is nu zo veralgemeend dat alle mogelijke indrukken of beelden die men zich van het huis in kwestie hebben gevormd of kunnen vormen daarin zijn opgenomen".

48. A.w., bl. 38 
selfs dat elke woord potensieel hetrekking het op die ganse heelal. Elders sê hy ${ }^{49}$ ): "It belongs to the nature of a ,word', as that word is universally understood, to he utillized over and over again in many different contexts and situations".

Teen hierdie algemeenheid en onbepaaldheid van 'n woord het die gewone spreektaal egter sy hesondere individualiseringsmiddele. Die woord huis kan inderdaad enige menslike woonplek aandui : van'n stroois tot die woonplek van president of keiser en reik verder tot „die huis van my Vader met sy baie woninge”. Ook hierin is beheersing, en dit toon die wye verskeidenheid moontlikhede van taal. Maar dit sluit die verbesondering, die meer gespesialiseerde beheersing nie uit nie, want ek kan huis nader individualiseer as: my/ons/'n/die/hierdie/dardie huis; die groot huis; 'n 4 vertrek-huis; die huis van my buurman; dic huis (net) on die draai; die teëldakhuis, ens., ens.

Maar teenoor hierdie algemeenleid of semantiese meervlakkigheid van die woord waarop die taal angewys is - waarin die digler jubileer en waarop die poësie dikwels steun - staan ook dat juis dit 'n duidelike openbaring van die mens se strewe na beheersing, finale en ahsolute hehecrsing, is dat hy hom nie altyd die vaagheid kan veroorloof nie. Hiervan getuig die baie individualiseringsmiddele, waarvan hierbo maar enkeles aangehaal is. Hoe noukeuriger en indringender die beheersing word -- soos in die beoefening van die wetenskap of in die uitoefening van gespesialiseerde vakwerk - hoe noukeuriger, presieser, finaler moet die inhoud van die woorde, hoe meer afgebakend moet die hetekenisgebied wees. Vir die gewone, alledaagse gehruiker is snelheid en spoed twee identiese hegrippe, maar die fisikus moet daaraan, vanweë sy hesondere heheersing van die bewegingsleer, lessondere, spesifieke en afsonderlike inhoude gee. Die woord gewig is vir die gewone gehruiker voldoende, maar die natuurwetenskaplike moet daaraan 'n hepaalde hetekenis toeken, wat nie meer vaag en algemeen is nie en ook in teenstelling staan tol massa. 'n Hokk het vir die wiskundige 'n heel ander gespesialiseerde hetekenis as vir die winkelier, vir wie dit besonder ekonomiese implikasies het; in albei stan teenoor die meervlakkige hetekenis van die alledaagse gebruik.

Die individualisering en presisering word hier dus soveel moontlik in die enkele woord saamgetrek, al word dit as simbool uitgedruk in 3C-48. Dit sluit egter nie iets soos interkontinentale ballistiese projektiel uit nie!

Met die aard en graad van die heheersing verskil onk die aard van die taal warin die heheersing geskied. Net so min as 'n moderne Boeingstraalvliegtuig met dieselfde instrumente helicer kan word as die vliegtuigie waarmee die Wrights hegin het, net so min kan dic moderne wetenskap heheers word met die taal van 'n natuurvolk. Hoe hoër die vorm van heheersing, hoe delikater word die middel, i.c. die taal, waarmee heheers word. Omdat die wetenskaplike kennis verder, as hoogste vorm van heheersing, van praktiese kemnis verskil daarin dat dit afstand doen van die hier

49. A.W., bl. 38 . 
en nou, hom distansieer van die praktiese geïnteresseerdheid in die gekende langs die weg van abstraksie en analise ${ }^{50} \%$, selfs in so 'n mate dat die taal in die wetenskapsheocfening die uitsonderlike funksie het dat dit die aard van die wetenskap hepaal, dat die wetenskap kwalifiseer ${ }^{51}$ ), word hierin veel hoër eise an die heheersingsmiddel gestel.

Daarom het ons ook ' $n$ roeping t.a.v. die taal in die wetenskap, nl. om dit 'n doeltreffende, doelmatige, adekwate, delikate, fyn ingeslypte middel te maak. Geen wetenskap kan hehoorlik beheers word en geen kennis daaromtrent suiwer en finaal oorgedra en ontvang word as die middel daartoe, die taal, nie ten volle dienlik gemalak is nie. Daar is geen houdbare verontskuldiging vir enige vakman as daar in sy vak nie 'n doelmatige vakterminologie in sy eie taal hestaan nie: om sy vak te leheers het hy die terminologie nodig en moet hy dit skep indien dit nie paraat is nie, en hy het al die vermoëns daartoe en al die materiaal om uit te put. Dit vra net roepingsbewuste en roepingsverantwoordelike volle gebruikmaking van hierdie vermoëns en materiaal om hulle tot dienshaarhejd te dwing. Want die mens is nie vir die taal gemaak nie maar die taal vir die mens.

Die wisselwerking tussen hepaaldheid en onbepaaldheid van die inhoud, betekenis of draagwydte van 'n woord lê op alle vlakke van die mens se beheersings. aktiwiteit: die mens rig, koördincer en sistematiseer sy denke en kennis in taal, iı woord en sin, en dit strek oor die hele wêreld en dek alle menslike aktiwiteite. (If hy 'n bok hekruip of 'n maaltyd berei, of hy 'n vakansiereis beplan of aan 'n spel dedneem, of hy 'i plaas aftree of dit deur 'n landmeter laat opmeet, of hy 'n span osse dryl of 'u trekker hestuur, of hy op sy horlosie kyk om vas te stel hoe laat dit is of jare en maande hereken in die verlede of die toekoms, of hy sy skape $t \in l$ of die wisselkoers tussen lande vasstel, of hy 'n hoek koop teen R2 of 'n plaas verkoop teen $R 20,000)$, of hy sy maandelikse hegroting opstel of die vorm vir die helastinggaarder invul, of hy 'il ysterstaal met'in kouleitel op die regte plek deurkap dan wel of hy met 'n siklotron die kern van 'n atoom splyt, of hy hom sil en verwonder oor die gedral van 'n mier of die gesirkel van 'n voël as hy die lugstrome ingehaal het dan wel of hy hom kwel oor Einstein se relatiwiteitsteorie, of hy 'n gedig maak, 'n opera komponeer of die verhoudinge, rangskikking en kleure van 'n skildery oorweeg - altyd en orals is die mens bewus of onbewus besig om die wêreld met sy taal te beheers.

Dit is juis die verontagsaming van die heheersingsfunksie wat Gardiner ${ }^{52}$ ) tot die volgende verkeerde uitspraak voer: "When someone asks the price of an article and is told Six and eightpence! he produces the money and the transaction is closed. The seller has employed the words Six and eightpence! merely as a

50. Van Riessen: a.w., bl. 10

51. Ibid., bl. 11 .

52. A.w., bl. 54. 
contrivance to ohtain his price. The words themselves are of supreme indifference (hierdie onderstreping deur my); the speaker may be unconscious of uttering them, and the listener of hearing them". Maar dit is nie die geval nie, want hierdie woorde van die handelaar is èn vir hom èn vir sy klant in sy wêreld en in hulle klimaat die middel waarmee die situasie (in hierdie geval 'n kooptransaksie) beheers word. Daarin is hulle net so helangrik, net so noodwendig en eksak en net so min „of supreme indifference" as wat binomium vir die wiskundige of jambe vir die letterkundige in hulle onderskeie wêrelde is. In en agter die prys wat die handelaar noem, is daar ekonomiese beheersingsaktiwiteit: prys- en winsherekening by die handelaar; hy die klant die oorweging van hetaalhaarheid, van verhouding tussen prys en waarde en ontheerlikheid. Gardiner se handelaar kon op die vraag van die klant net sowel 'n prysetiket met $6 / 8$ daarop aan die klant getoon het, en dan het hy geen enkele woord uitgespreek nie, en die transaksie kon nog beklink gewees het. Maar dit heteken nie dat èn handelaar èn klant nie talig hesig was nie : alhei het in taal gedink, in taal beheers. Dit onderstreep egter weer eens die heperkinge van die opvatting dat taal net in kommunikasie hestaan.

4

Die wil van God mel die mens en sy taal blyk uiteindelik nie uit die verwarring en wanhegrip van Bahel nie, maar dit hlyk hy die uitstorting van die Heilige Gees. Hier is die getuienis van die luisterende vreemdelinge in Jerusalem: „Ons hoor hulle in ons eie taal oor die groot dade van God spreek". In Christus, sê Woltjer ${ }^{33}$, is al die skatte van wysheid en kemnis verborge (Kol. 2 : 3). Eu deur Christus weer in gemeenskap met Cod herstel, ontvang die mens uit Hom weer die lig om die waarheid te ken. Hy herstel die logos in dié wat aan Itom behoort -omdat die heerlikheid en die diepte van die Woord van Cod ann hulle ontsluit is, nie omdat hulle uit hulleself meer as ander vermag nie : in die Lig sien hulle die lig! „En dit is hun voorrecht, dat zij van alles wat zij weten den laasten grond kennen; dat zij in alle kemnis, in elke nicuwe ontdekking, dat zij in de geestelijke en in de stoffelijke wereld en hare verschijnselen de hecrlijkheid herkemmen en aanhidden van Hem, door wien en tot wien alles is".

Dic niteindelike funksie van die taal op alle vlakke, ook op die gebied van die weteuskap, is dan ook: dis middlel om in te spreek oor die groot dade van God. Die heoefening van die wetenskap moet nie oor die wêreld'n kakofonie laat loshreek van verwarde stemme van mense en nasies wat vir hulleself naam wil maak soos hy Bahel nie, maar dit moet 'n harmoniese lofsang in duisenderlei stem wees, dit moet deurdring tot die wonder van die skepping en tot die besef van die wonderbare van die God van die skepping.

53. „De wetenschap van den logos" in a.w., bl. 33, 34. 
Só vertolk die digter Revius dit in sy sonnet "Scheppinge":

God heeft de wereld door onzichtbare klavieren (snare)

Betrokken als een luit met al zijn toebehoor.

Den hemel is de bocht vol reien door en door,

Het roosken, zon on maan die om ons hene zwieren.

Twee grove bassen die staag bulderen en tieren

Zijn d'aard' en d'oceaan: de kwinte die het oor

Verheuget, is de locht: de reste die den koor

Volmaket, is 't geboomt en allerhande dieren.

Dees luite sloeg de Heer met zijn geleerde vingers,

De engels stemden in als treffelijke zingers,

De hergen hoorden toe, de vloeden stonden stil:

Den mens alleen en hoort noch zangeren noch snaren,

Behalven dien it de Heer belieft te openbaren

$\mathrm{Na}$ zijn bescheiden raad en Goddelijken wil.

Dít is dan ook die hoogste prestasie van die mens in die volvoering van sy lestemming as mens: behcersing in die wonder van sy taul van die wonders wat God se skepping omsluit.

Dan is wetenskapsleoefening meer as net versamoling van feite en uitbreiding van kennis van leermeester en leerling. Wetenskapsheoefening is in dic grond ook nebed - gebed om in " Lig die lig te sien; is ook belydenis - belydenis van cie onvermoë en onvolkomenleid; is ook verkondiging - verkondiging van die grootheid van God in die skepping; dis amps- en roepingsvervulling, beheersing, onderwerping, ontginning en onthulling van die wonders van God deur die wonder van die woord. Hier verval alle selfvergestalting en selfverwesenliking; hier bly alleen oor die spreek oor die groot dade van God tot eer van God.

En daartoe het die mens net een middel: die taal.

HERTZOG VENTER. 